\title{
A New Perspective on Quality Characteristics Determining Supply Chain Management of Coffee Production
}

\author{
Ana Horvat, Slobodan Antic, Veljko Jeremic
}

\author{
University of Belgrade \\ Jove Ilica 154, 11000, Belgrade, Serbia \\ E-mail.horvat@fon.bg.ac.rs, slobodan.antic@fon.bg.ac.rs,veljko.jeremic@fon.bg.ac.rs
}

cross $^{\text {ref }}$ http://dx.doi.org/10.5755/j01.ee.26.3.5462

\begin{abstract}
This paper explores the differences in the quality perception of coffee among different participants in the supply chain management of coffee production. Rather, the aim of this paper was to answer the question of whether a particular level of coffee quality is the same for all participants in the supply chain. Also, we wanted to respond to the issue of whether all participants in the supply chain equally valued its characteristic. As a possible remedy to the problem, two-stage PCA-Idistance approach has been performed. The results have shown that there are indeed differences in the quality perception of coffee among different participants in the supply chain. Also, we proposed framework for emphasizing significant components for respective participant, and within crucial quality characteristics. Therein, we determined the most significant component which encompasses following set of characteristics of the coffee supply chain for distributor: the coffee inventory turnover ratio, producer satisfaction with distributor services, customer satisfaction (retail) with distributor services. Likewise, same procedure was done for producer and analysis pointed out following quality characteristics: the coffee's country of origin, the manufacture date, the expiry date, storage cost of the final product, customs procedures, delays in procurement, and the temperature of at which the coffee is roasted.
\end{abstract}

Keywords: product quality, distribution quality, quality perception, PCA-I-distance approach, supply chain management.

\section{Introduction}

The goal of producers is to supply a product to customers that meets the customers' needs, though this need not necessarily mean that they have adequately recognized the needs of the final users (Migliore et al., 2015; Parmigiani \& Rivera-Santos, 2015; Wong et al., 2011). In addition, before being consumed, the product must pass through the appropriate distribution chain to reach the user. (Gupta \& Singh, 2012) define the service quality in supply chain as how well an organization meets or exceeds the customer expectations in unidirectional or bidirectional way for each element of a supply chain i.e. supplier, manufacturer, distributor, retailer and customer or end consumer. This fact raises the question, whose answer is also the aim of this study, as to whether a particular level of coffee quality is equal for all participants throughout the supply chain, and as to whether certain characteristics rate equally in their importance to all participants. For instance, whereas actually cup quality is the primary criterion in consuming countries, coffee's direct physical quality is mainly assessed through the physical aspects of coffee beans, such as its colour, size, density, and percentage of physical defects in producing countries (Vaast et al., 2006). Numerous factors affect coffee quality (Clifford \& Wilson, 1985), including soil water status (Carr, 2001), climatic conditions (Vaast et al., 2002), the maturity of coffee berries at their harvest, bean processing (fermentation, washing, drying, storage, roasting, and beverage preparation), agricultural management (shade, pruning, and fertilisation), and the genetic properties of the cultivars (Bertrand et al., 2003). In this regard of examining overall coffee quality, several quality characteristics of coffee for participants in the coffee supply chain in Serbia are defined and analysed in this study.

(Rosenblom, 1999) distinguishes between title flow, negotiation flow, product flow, finance flow, information flow, and promotion flow. Receiving special attention in this study is the aspect of the flow of the product, namely how members at different stages in the national distribution chain of coffee perceive product quality; i.e., if chain members perceive quality requirements differently, they will pursue different quality characteristics of a product. Quality perception is the cognitive response to a service experience (Petrick, 2004). Although, there has been much research on distribution chains (Stern et al., 1996), few studies in the literature on supply chains have examined how members at different stages in the distribution chain separately perceive the quality of the products offered. (Korneliussen \& Gronhaug, 2003) do find that producers and exporters emphasise distribution quality while importers and supermarkets emphasise product quality. These authors believe this difference in preference stems from a division of labour in distribution, where chain stages undertake activities according to their role in the distribution chain. In the case of production and distribution of quality, chain stages' roles and activities influence their perceived quality perceptions. Korneliussen and Gronhaug's findings also reveal that upstream members in the distribution chain stress distribution quality, while firms that are located downstream in the supply process tend to emphasize product quality. (Houston \& Sudman's, 1975) research shows that chain stages have different quality perceptions based on their roles in the 
distribution chain. The role these perform determines their goals and activities, through whose interaction between adjacent chain stages influences their quality perceptions. For example, suppliers want to know what quality characteristics buyers want and what quality level is expected so that they can arrange their activities accordingly (Zu \& Kaynak, 2012).

In this study, our aim is to determine if the differences exist in the quality perception of coffee among different participants in the supply chain. In addition, we wanted to examine the most important component for producers in the coffee supply chain and distributors, as well. Moreover, quality characteristics as integral part of examined components will be scrutinized as well.

Producers have a reason for ensuring large downstream inventories: to provide high distributor service levels to maintain or gain market share (Schwarz \& Zhao, 2011). Also, rapid global changes in the environments of industrial markets make distributor commitment more important to producers and in some ways harder to achieve (Goodman $\&$ Dion, 2001). Having previously said, the purpose of this study has been to ascertain whether any differences in the quality perception among producers and distributors of coffee in Serbia exist. To achieve this aim, a sample of 16 organizations, 11 distributors, and 5 producers with a major presence (Companies Market, 2014; Balkan Peace, 2014) in the Serbian coffee market have been observed. Accordingly, the following hypotheses have been defined:

H1: A systematic change of quality perceptions through the coffee supply chain is present.

H2: Proposed framework emphasizes significant components for respective participant, and within crucial quality characteristics.

\section{Research Methodology}

In order to examine our hypotheses, appropriate questionnaire has been introduced. The quality characteristics, for producers and distributors in the coffee supply chain, were defined by conducting interviews with the managers of coffee manufacturing and distributing organizations in the Serbian market. These characteristics were base on KPI's (Key Performance Indicators) in supply chain (Hugos, 2011; Dubey, 2011). Questionnaire used in the study had first been sent to all organizations that were currently active in the Serbian coffee market; the respondents were managers of coffee manufacturing and distributing organizations. The questionnaire itself consisted of two parts: the first contained questions on the quality characteristics of the coffee supply chain for the producer, and the second included questions on the quality characteristics of the coffee supply chain for the distributor. The quality perception of participants in the coffee supply chain was measured using variable Significance, which measures the importance of the quality characteristics participants assigned to the coffee supply chain. For creating this variable, a 5-point Likert scale was used.

With growing need for impartial rankings, one of the devised methodologies, which could answer such a task, was the I-distance methodology developed by (Ivanovic, 1977). Proposed metric solves the issue of incorporating various indicators of different measurement units into a single synthetic indicator (Jeremic et al., 2012). Another important aspect is its ability to overcome the problem of subjectivity in a composite indicator (Dobrota et al., in press). In order to apply the I-distance methodology, it is necessary to fix one entity as a reference in the observed data set. The fixed or referent entity is the entity with the minimal value for each indicator (or a fictive entity with minimal value of each indicator). The ranking of entities in the data set is founded on the calculated distance from the referent entity (Jovanovic et al., 2012). The construction of the I-distance is an iterative process, which can consist of several steps. The first step calculates the amount of discriminate effect of the first variable (the most significant variable that provides the most information on the ranking phenomenon); the second step calculates the value of the discriminate effect of the second variable, not included in the first. This procedure is repeated for all the variables in the observed data set (Seke et al., 2013). Consequently, the procedure calculates the correlations between the I-distance values and input variables. Correlations are used because of the special feature of the I-distance method: It is able to present the relevance of input indicators. The I-distance method defines which of the input indicators are most important for the ranking process by putting them into a specific order of importance according to these correlations.

Let $X^{T}=\left(X_{1}, X_{2}, \ldots X_{k}\right)$ be a set of variables chosen to characterize the entities. I-distance between two entities $e_{r}=\left(x_{1 r}, x_{2 r}, \ldots x_{k r}\right)$ and $e_{s}=\left(x_{1 s}, x_{2 s}, \ldots x_{k s}\right)$ is defined as

$$
D(r, s)=\sum_{i=1}^{k} \frac{\left|d_{i}(r, s)\right|}{\sigma_{i}} \prod_{j=1}^{i-1}\left(1-r_{j i .12 \ldots j-1}\right)
$$

where $d_{i}(r, s)$ is the discriminate effect (distance between the values of the variable $X_{i}$ for $e_{r}$ and $e_{s}$ ),

$$
d_{i}(r, s)=x_{i r}-x_{i s} \quad i \in\{1, \ldots k\}, \quad \sigma_{i} \quad \text { is the }
$$
standard deviation of $X_{i}$ and $r_{j i .12 \ldots j-1}$ is the partial coefficient of the correlation between $X_{i}$ and $X_{j},(j<i)$ (Jeremic et al., 2011; Radojicic \& Jeremic, 2012). In addition, frequently used square I-distance (Jeremic et al., 2013) is given as:

$$
D^{2}(r, s)=\sum_{i=1}^{k} \frac{d_{i}^{2}(r, s)}{\sigma_{i}^{2}} \prod_{j=1}^{i-1}\left(1-r_{j i .12 \ldots j-1}^{2}\right)
$$

\section{Results}

The results of testing the initial assumptions are given below in Table 1 and Table 2. They are broken down into quality characteristics of the coffee supply chain by distributor for Table 1 and quality characteristics of the coffee supply chain by producer for Table 2 . After applying PCA method, three components incorporated the most significant characteristics of both producers and distributors. Afterwards, the I-distance method was used to determine which components are the most important for the respective participant in the supply chain. In addition, component loadings as the correlations between quality characteristics and component provide an in-depth overview of the most significant characteristics. 
Quality Characteristics of the Coffee Supply Chain by Distributor DISTRIBUTOR

\begin{tabular}{|c|c|c|c|}
\hline & \multicolumn{3}{|c|}{ Component } \\
\hline & 1 & 2 & 3 \\
\hline coffee inventory turnover ratio & & & 0,887 \\
\hline producer satisfaction with the distributor's services & & & 0,714 \\
\hline customer satisfaction (retail) with the distributor's services & & & 0,654 \\
\hline documentation of the distributor's medical safety of products & & 0,921 & \\
\hline accuracy of delivery & & 0,873 & \\
\hline the completeness and accuracy of transport documentation & & 0,859 & \\
\hline storage of coffee in the distributor's warehouse & & 0,854 & \\
\hline storage cost of goods (coffee) in the distributor's warehouse & 0,854 & & \\
\hline the number of complaints from distributors & 0,787 & & \\
\hline the number of defective pieces from the distributor & 0,739 & & \\
\hline quantity and value of wastage, breakage, and write-offs & 0,729 & & \\
\hline the number of complaints from the final customer & 0,707 & & \\
\hline order size and frequency of orders & 0,687 & & \\
\hline the cost of the transportation of the goods & 0,672 & & \\
\hline waiting time for manufacturers' trucks to unload goods & 0,668 & & \\
\hline the number of defective pieces at the distributor & 0,665 & & \\
\hline correlation with the I-distance & 0,328 & 0,639 & 0,679 \\
\hline
\end{tabular}

Quality Characteristics of Coffee Supply Chain by Producer

Table 2 PRODUCER

\begin{tabular}{|c|c|c|c|}
\hline & \multicolumn{3}{|c|}{ Component } \\
\hline & 1 & 2 & 3 \\
\hline the coffee's country of origin & 0,973 & & \\
\hline the date of manufacture and expiry date & 0,973 & & \\
\hline the storage cost of the final product & 0,973 & & \\
\hline customs procedures and delays in procurement & 0,886 & & \\
\hline the temperature at which the coffee is roasted & 0,840 & & \\
\hline the unit price of the final product & & 0,992 & \\
\hline the quantity and value of sale of final products & & 0,992 & \\
\hline the storage of raw coffee & & 0,877 & \\
\hline physical properties of the coffee & & 0,771 & \\
\hline the quality of unit packaging & & 0,713 & \\
\hline the time needed to cool roasted coffee & & 0,677 & \\
\hline transport packaging types & & 0,671 & \\
\hline the chemical properties of unit packaging & & 0,630 & \\
\hline moisture management of roasted coffee & & & 0,963 \\
\hline the cost of quality in manufacturing & & & 0,963 \\
\hline the internal costs of raw coffee & & & 0,929 \\
\hline milling method & & & 0,644 \\
\hline correlation with the I-distance & 0,530 & 0,506 & 0,480 \\
\hline
\end{tabular}

The first assumption $\mathrm{H} 1$ implies that a systematic change of quality perceptions through the coffee supply chain does exist. The results show that there is indeed a difference in quality perceptions through the coffee supply chain between producers and distributors. Results showed that the correlation with the I-distance of Component 3 for the distributor is 0.679 , that essentially proves that this component is the most important for the distributor. This component encompasses following set of quality characteristics: coffee inventory turnover ratio (an inventory turnover ratio measures the number of units dispensed in relation to the average unit inventory, Sorooshian et al., 2013), producer satisfaction with the distributor's services, and customer satisfaction (retail) with the distributor's services. The correlation with the I-distance for Component 1 for the producer is 0,53 , demonstrating the most important component for the producer. This component encompasses the coffee's country of origin, the date of manufacture and the expiry date, the storage cost of the final product, customs procedures and delays in procurement, and the temperature at which the coffee is roasted. These results all lead to the conclusion that producers and distributors differently evaluate quality characteristics throughout the coffee supply chain. The second assumption $\mathrm{H} 2$ is in concordance with suggested framework. It emphasises critical components both for the producer and distributor in the coffee supply chain and within crucial quality characteristics (i.e. for distributor - coffee inventory turnover ratio, etc.; the coffee's 
country of origin, etc. for producer). The results obtained within do confirm this hypothesis.

The coffee inventory turnover ratio characteristic is important to distributors due to the freshness. As the higher inventory turnover there is, the better the shelf life of the products tends to be, which should result in the customer receiving a fresher product. This same characteristic denotes distributor intensities for the sale and flow of the item, which bear a direct impact on sales margins (i.e. the earnings of distributors). A higher turnover ratio, together with desired inventory availability, demonstrates the effective use of resources for distribution of products throughout the supply chain (Bowersox, 2007). Inventories are often rotated during observation periods (for instance, by month or quarter). If the coffee inventory turnover ratio is greater, the organization automatically has less stock. A decrease in inventory accompanies a lower occupancy of storage, by that reducing the cost of the holding inventories of the product. In such cases, the free space in storage could be used for other items. This approach would be highly expressive for the sale and distribution of coffee due to the fact that it is a product that necessitates large dimensions (while the unit weight of coffee is light, the boxes in which coffee is packaged demand a large volume of space while stored in a warehouse). In addition, distributors can use the coffee inventory turnover ratio as a benchmark to compare the efficiency of their logistics processes with that of competitors. The producer's and user's (retail store) satisfaction with their services are also important for distributors, which could stem from the need for obtaining and maintaining an exclusive agreement for the distribution of coffee, or the opinions of producers and retail distributors in regard to the quality of service and its ability to deliver specific products (accuracy, speed, and precision in delivery).

Based on the data analysis, one of the essential characteristics for the producer is the coffee's country of origin. Since the quality of the final product depends on the quality of the raw materials, it is only natural that there would be an interest into where these materials originate. Also, caffeine content of coffee is determined by country of origin of coffee (McCusker et al., 2003). It would appear that the coffee's country of origin is also important due to the price at which the coffee is purchased having a direct impact on the cost of the final product. In addition, the cost and time of delivering the goods depend on the distance of the raw materials from the producer, directly affecting price. The date of manufacture and expiry date are both especially important for traceability, arising from the necessity of customer complaints about the quality of coffee which needing to be tested from the end user to the producer, as well as from the quantity of inventory in storage and the management of these stocks. The storage cost of the final product assigns particular importance itself, as stocks of raw materials are made in the season of the production of green coffee and hence heavily influenced by production seasons. Within, the price of coffee varies on the market, commonly being purchased in large quantities when the price of raw coffee is lower, which is after that stored by the producer. The cost of storage for this reason has a direct impact on the final cost of the product and the producer's logistics processes. Customs procedures and delays are also important due to the availability of raw coffee for the producer. The temperature of the coffee itself directly affects the taste of coffee and the customers' perception of the brand of coffee. Finally, the temperature at which the coffee is roasted is a critical operation as the quality of the coffee depends most on this characteristic.

\section{Conclusion}

The results of this study prove to be useful in the analysis of coffee supply chains since they examine the most important quality components for both producers and distributors in such supply chains. The additional analysis has established that the most important component for distributors encompasses following quality characteristics: (1) coffee inventory turnover ratio, (2) producer satisfaction with the distributor's services and (3) customer satisfaction (retail) with the distributor's services, and those for producers have been found as: (1) the coffee's country of origin, (2) the date of manufacture and expiry date, (3) the storage cost of the final product, (4) customs procedures and delays in procurement and (5) the temperature at which the coffee is roasted. This implies that a systematic change of quality perceptions through the coffee supply chain does exist. The results show that there is indeed a difference in quality perceptions through the coffee supply chain between different participants, which advocates in favour of hypothesis H1. The results also imply that the most important components in the coffee supply chain for producer encompass crucial quality characteristics such as: the coffee's country of origin, the date of manufacture and the expiry date, etc. In addition, the same approach is used for distributors and several prominent quality characteristics have been singled out; thus confirming our hypothesis $\mathrm{H} 2$.

The results have shown that distributors recognize the need to take into account producers' and users' (retail stores) satisfaction with their services due to the benefits of maintaining a high level of user satisfaction. The subsequent recommendation would within be for distributors to monitor the satisfaction level of their users (producers and retail stores) in order to improve their service. The results could prove useful in improving the quality of the product (coffee) to the final consumer and enhance the quality of the supply chain. Based on the results obtained in the study, a system of KPI (Key Performance Indicators) could be formed, one in which indicators would be followed to improve the coffee supply chain. Recognition of the most important components of the supply chain according to customers and other stakeholders should lead to a better understanding of customer requirements. Future research should extend to the improvement of coffee packages (eco-cheaper packs), a KPI system for the supply chain management of coffee, customer satisfaction, and cost reduction in the distribution chain (reducing inventory and distribution costs). 


\section{Acknowledgement}

We are grateful for reviewers' comments and suggestions that helped us reshape and improve our paper.

\section{References}

Balkans Peace (2014). Serbian coffee firm gets EBRD loan for Bosnia plant. Available from the internet: http://www.balkanpeace.org/index.php?index=article\&articleid=12399.

Bertrand, B., Guyot, B., Anthony, P., \& Lashermes, P. (2003). Impact of the Coffea canephora gene introgression on beverage quality of C. arabica. Theoretical and Applied Genetics, 107(3), 387-395. http://dx.doi.org/10. 1007/s00122-003-1203-6

Bowersox, J. D. (2007). Supply Chain Logistics Management. New York: McGraw Hill Irwin.

Carr, M. K. V. (2001). The water relations and irrigation requirements of coffee. Experimental Agriculture, 37(1), 1-36. http://dx.doi.org/10.1017/S0014479701001090

Clifford, N. M., \& Wilson, K. C. (1985). Coffee: Botany, Biochemistry and Production of Beans and Beverage. London, UK: Croom Helm. http://dx.doi.org/10.1007/978-1-4615-6657-1

Companies Market (2014). Coffee Consumption in Serbia. Available from the internet: http://www.companiesandmarkets. com/News/Food-and-Drink/Coffee-Consumption-in-Serbia-to-Reach-39-515-tonnes-in-2015/NI2391.

Dobrota, M., Bulajic, M., Bornmann, L., \& Jeremic, V. (in press). A new approach to QS University Ranking using composite I-distance indicator: uncertainty and sensitivity analyses. Journal of the Association for Information Science and Technology. doi:10.1002/asi.23355 http://dx.doi.org/10.1002/asi.23355

Dubey, R. (2011). Improving Firm Performance through Logistics Activities: A Research Framework. Indian Journal of Commerce \& Management Studies, 2 (1), 75-86.

Goodman, L. E., \& Dion, P. A. (2001). The Determinants of Commitment in the Distributor-Manufacturer Relationship. Industrial Marketing Management, 30(4), 287-300. http://dx.doi.org/10.1016/S0019-8501(99)00092-9

Gupta, T. K., \& Singh, V. (2012). Service Quality in Supply Chain: A Review. International Journal of Engineering \& Technology, 2(8), 1395-1404.

Houston, M. J., \& Sudman, S. (1975). A methodological assessment of the use of key informants. Social Science Research, 4(2), 151-164. http://dx.doi.org/10.1016/0049-089X(75)90009-5

Hugos, H. M. (2011). Essentials of Supply Chain Management. USA. John Wiley \& Sons http://dx.doi.org/10. $1002 / 9781118386408$

Ivanovic, B. (1977). Classification Theory. Belgrade, Serbia: Institute for Industrial Economics.

Jeremic, V., Bulajic, M., Martic, M., \& Radojicic, Z. (2011). A fresh approach to evaluating the academic ranking of world universities. Scientometrics, 87(3), 587-596. http://dx.doi.org/10.1007/s11192-011-0361-6

Jeremic, V., Bulajic, M., Martic, M., Markovic, A., Savic, G., Jeremic, D., \& Radojicic, Z. (2012). An Evaluation of European Countries Health Systems through Distance Based Analysis. Hippokratia, 16(2), 170-174.

Jeremic, V., Jovanovic-Milenkovic, M., Martic, M., \& Radojicic, Z. (2013). Excellence with Leadership: the crown indicator of SCImago Institutions Rankings IBER Report. El Profesional de la Informacion, 22(5), 474-480. http://dx.doi.org/10.3145/epi.2013.sep.13

Jovanovic, M., Jeremic, V., Savic, G., Bulajic, M., \& Martic, M. (2012). How does the normalization of data affect the ARWU ranking? Scientometrics, 93(2), 319-327.

Korneliussen, T., \& Gronhaug, K. (2003). Quality perceptions in international distribution: an empirical investigation in a complete distribution chain. Supply Chain Management: An International Journal, 8(5), 467-475. http://dx.doi.org/10.1108/13598540310500295

McCusker, R. R., Goldberger, B. A., \& Cone, E. J. (2003). Caffeine Content of Specialty Coffees, Journal of Analytical Toxicology, 27(7), 520-522.

Migliore, G., Schifani, G., Cembalo, L. (2015). Opening the black box of food quality in the short supply chain: Effects of conventions of quality on consumer choice. Food Quality and Preference, 29, 141-146. http://dx.doi.org/10. 1016/j.foodqual.2014.07.006

Parmigiani, A., \& Rivera-Santos, M. (2015). Sourcing for the base of the pyramid: Constructing supply chains to address voids in subsistence markets. Journal of Operations Management, 33-34, pp. 60-70. http://dx.doi.org/10. 1016/j.jom.2014.10.007

Petrick, J. F. (2004). The roles of quality, value and satisfaction in predicting cruise passengers' behavioural intentions. Journal of Travel Research, 42(4), 397-407. http://dx.doi.org/10.1177/0047287504263037

Rosenblom, B. (1999). Channels of distribution. In M. Baker (Ed.), The IEBM Encyclopedia of Marketing (pp. 100-113). London: International Thompson Business Press. 
Radojicic, Z., \& Jeremic, V. (2012). Quantity or quality: What matters more in ranking higher education institutions? Current Science, 103(2), 158-162.

Schwarz, L.B., \& Zhao, H. (2011). The Unexpected Impact of Information Sharing on US Pharmaceutical Supply Chains. The INFORMS Journal on the Practice of Operations Research, 41(4), 354-364. http://dx.doi.org/10. 1287/inte.1110.0571

Seke, K., Petrovic, N., Jeremic, V., Vukmirovic, J., Kilibarda, B., \& Martic, M. (2013). Sustainable development and public health: rating European countries. BMC Public Health, 13(77). http://dx.doi.org/10.1186/1471-2458-13-77

Sorooshian, S., Jambulingam, M., \& Dodangeh, J. (2013). Case Study on Logistics Performance. International Journal of Engineering Business Management, 5(14), 1-5. http://dx.doi.org/10.5772/56264

Stern, L. W., El-Ansary, A. I., \& Coughlan, A. T. (1996). Marketing Channels, 5th ed., London: Prentice-Hall International.

Vaast, P., Bertrand, B., Perriot, J. J., Guyot, B., \& Genard, M. (2006). Fruit thinning and shade improve bean characteristics and beverage quality of coffee (Coffea arabica L.) under optimal conditions. Journal of the Science of Food and Agriculture, 86(2), 197-204. http://dx.doi.org/10.1002/jsfa.2338

Vaast, P., Genard, M., \& Dauzat, J. (2002). Modeling the effects of fruit load, shade and plant water status on coffee berry growth and carbon partitioning at the branch level. Acta Horticulturae, 584, 57-62.

Wong, H., Potter, A., \& Naim, M. (2011). Evaluation of postponement in the soluble coffee supply chain: A case study. International Journal of Production Economics, 131 (1), 355-364. http://dx.doi.org/10.1016/j.ijpe.2010.08.015

$\mathrm{Zu}$, X., \& Kaynak, H., (2012). An agency theory perspective on supply chain quality management. International Journal of Operations \& Production Management, 32(4), 423-446. http://dx.doi.org/10.1108/01443571211223086

The article has been reviewed.

Received in October, 2013; accepted in June, 2015. 